Ю.М. Пащук

Національна академія сухопутних військ ім. гетьмана П. Сагайдачного, Львів

\title{
СПРОМОЖНОСТІ ТА ТЕНДЕНЦІЇ РОЗВИТКУ ОБ'ЄДНАНОЇ СИСТЕМИ ВИВЧЕННЯ ТА ВПРОВАДЖЕННЯ ДОСВІДУ НАТО
}

В статті розглянуто теоретичні основи організаційного вивчення і впровадження досвіду у збройних силах країн-членів Північноатлантичного Альянсу, а також досліджено історичні аспекти створення Об'єднаної системи вивчення та впровадження досвіду НАТО. Проаналізовано головні спроможності даної системи за чотирма напрямами: організачійна структура; стандартизований прочес вивчення $i$ впровадження досвіду; підготовка особового складу із питань вивчення і впровадження досвіду; засоби, шяо використовуються для вивчення та впровадження досвіду.

У роботі також досліджено основні проблеми функціонування Об'єднаної системи вивчення $i$ впровадження досвіду НАТО, розглянуто тендениії подальшого ї̈ розвитку.

Ключові слова: досвід, організачійне вивчення і впровадження досвіду, спроможності системи вивчення і впровадження досвіду, Об 'єднана система вивчення і впровадження досвіду НАТО.

\section{Вступ}

Постановка проблеми. Успішність діяльності будь-якої організації значною мірою залежить від дієвості вивчення та поширення отриманих знань i досвіду, а також від ефективності їх трансформування у коригувальні дії для покращення відповідної діяльності. Здатність адаптуватися та постійно удосконалюватися $є$ надзвичайно важливим у військовій справі, де вивчення та впровадження досвіду (ВВД), насамперед бойового, було, є і буде рушійною силою іï еволюційного розвитку.

Нині, в умовах реальної загрози ведення Росією більш масштабної війни проти України [1], одне 3 головних питань - чи готові Збройні Сили (3С) України зупинити агресора і дати йому належну відсіч? У цьому контексті ключовим завданням є якнайшвидше завершення формування перспективної Системи ВВД, що розпочалося у січні 2019 року [2, С. 2-5]. Головним призначенням такої Системи є покращення всіх видів діяльності 3С України, передусім, підвищення ефективності підготовки та бойового застосування військ (сил) [3-5]. Дана Система створюється на основі попередньої Системи узагальнення та поширення досвіду, що діяла у ЗС України з грудня 1991 року по грудень 2018 року [3, С. 36], спираючись на базові теоретичні та практичні засади організаційного ВВД, що здійснюється у збройних силах країн-членів Північноатлантичного Альянсу [3-5]. Власне у 3С України будується Система ВВД, фундаментом якої слугують основні нормативні документи функціонування Об'єднаної системи вивчення і впровадження досвіду (ОСВВД) НАТО [3-11]. Це дає змогу, насамперед, використовувати передові досягнення та напрацювання країн Альянсу щодо здійснення ефективного організаційного ВВД, а також забезпечувати сумісність військ (сил) України та держав-членів НАТО
[3, С.41]. Саме тому дослідження спроможностей, проблем і тенденцій розвитку ОСВВД НАТО є актуальним науково-практичним завданням.

Аналіз останніх досліджень і публікацій. Теоретичне обгрунтування та практичне застосування напівформальних процедур організаційного ВВД було започатковано у збройних силах Німеччини та Великобританії під час Першої світової війни [1214]. У період Другої світової війни та розгортання "Холодної війни” у багатьох країнах, зокрема і у Радянському Союзі, здійснювався подальший розвиток теорії та практики організаційного ВВД [3; 12-15].

Фундаментальні засади концепції організаційного ВВД (organisational learning) були розроблені у 1963 році американськими науковцями Річардом Сієртом і Джеймсом Марч у роботі [16]. Згідно 3 даною концепцією у військовій справі організаційне ВВД розглядається як “процес, за допомогою якого військова організація (наприклад, збройні сили, вид збройних сил, рід військ, військова частина, установа, заклад, підрозділ тощо) використовує нові знання, отримані на підставі здобутого досвіду або ж проведених досліджень, для коригування інституційних норм, доктрин і процедур із метою мінімізації ризику повторення помилок і збільшення шансів досягнення успіхів і перемог у майбутньому” [12-14; 16].

Наприкінці XX століття завдяки стрімкому науково-технічному прогресу, і насамперед розвитку інформаційно-комунікаційних технологій (IКT), були створені передумови для значного покращення можливостей із оперативного вивчення та поширення знань і досвіду [11-14]. На зламі тисячоліть, між 1995 та 2005 роками, вищенаведений фактор також спричинив подальший розвиток концепції організаційного ВВД і появу новітніх доктрин із управління знаннями (knowledge management), зокрема і теорії управління ВВД [12-14]. 
Зазначена теорія спрямована на дослідження шляхів покращення дієвості здобування знань і досвіду як із “внутрішнього” (організаційного) середовища, так із “зовнішнього” (позаорганізаційного) середовища, їх зберігання, архівування, відновлення та поширення у межах організаційного середовища для інформування особового складу і подальшого їх впровадження [12-14]. Також у фокусі теорії управління ВВД - ретельне вивчення шляхів підвищення ефективності використання явних і неявних знань на індивідуальному й організаційному рівні, напрямів застосування досягнень в галузі ІКТ для покращення процесу ВВД тощо [12-14].

Для оцінювання дієвості організаційного ВВД у теорії управління вивченням і впровадженням досвіду використовується низка комплексних показників якості. Серед них слід виокремити “абсорбуючу здатність" (absorptive capacity - ACAP) організації, що визначає іiї динамічні спроможності з організаційного ВВД (dynamic organisational capabilities) і стосується [12-14]:

1) здобування знань i досвіду (knowledge acquisition) за результатами грунтовного і всебічного аналізу спостережень;

2) керування пізнанням і використанням знань i досвіду (knowledge management) завдяки широкому застосуванню ІКТ і відповідних баз даних;

3) поширення знань i досвіду (knowledge dissemination);

4) трансформування знань і досвіду (knowledge transformation) через впровадження коригувальних дій для покращення результатів відповідної діяльності.

При цьому перші три вищенаведені аспекти ВВД формують “потенційну абсорбуючу здатність" організації (potential absorptive capacity - PACAP) [12-14]. Ключовим виміром, що застосовується у теорії управління ВВД, є динамічна спроможність організації трансформувати отримані знання і досвід у коригувальні заходи для покращення своєї діяльності, генеруючи тим самим “реалізовану абсорбуючу здатність" (realised absorptive capacity - RACAP) [13].

Одним із прикладів практичної реалізації концепції організаційного ВВД було проведення у збройних силах США у 1960-х роках успішного експерименту із упровадження у військах аналізу проведених дій (АПД, After Action Review - AAR) за результатами виконання поставлених завдань. Матеріали такого аналізу були грунтовним джерелом ініціативних і формальних спостережень, що узагальнювалися та трансформувалися у вивчені й упроваджені уроки.

Іншим прикладом втілення на практиці концепції організаційного ВВД та теорії управління ВВД було застосування у 1984 році в американській армії методики формального вивчення і впровадження досвіду за результатами проведення воєнної операції
“Urgent Fury” у Гренаді [3; 18-20]. Вперше вказану методику використала дослідницька група ЗС США, яку очолював полковник Уеслі Кларк [18-22]. Наступного року на базі зазначеної групи був створений Центр сухопутних військ США з вивчення і впровадження досвіду (Center for Army Lessons Learned $C A L L)$ [3; 18-20]. Головними напрямами діяльності такого центру були збір і аналіз спостережень, поширення й архівування інформації про вивчені та впроваджені уроки у сухопутних військах США, включаючи інформацію про бойовий досвід [3; 18-19].

Успішна апробація аналізу проведених дій, а також висока ефективність функціонування центру $C A L L$ стали фундаментом для формування у кінці 1980-х років Системи ВВД збройних сил США (US Joint Lessons Learned System) [3; 18-22]. Одним із перших вагомих здобутків функціонування новоствореної Системи було кардинальне удосконалення більшості доктринальних документів у всіх видах збройних сил США за результатами застосування американських військ у Кореї та В'єтнамі [20-22].

Протягом наступних 15 років зазначена система постійно еволюціонувала і стала взірцем для створення на початку 2000-х років ОСВВД НАТО та іiі складових - національних систем вивчення і впровадження у збройних силах країн-членів Альянсу [3; $11-14 ; 18-23]$.

Мета статті - дослідити спроможності Об'єднаної системи вивчення і впровадження досвіду НАТО та тенденції іiі розвитку для якісного формування і забезпечення ефективного функціонування перспективної Системи вивчення і впровадження досвіду Збройних Сил України.

\section{Виклад основного матеріалу}

Об'єднана система вивчення і впровадження досвіду НАТО - це одна із форм організаційного ВВД, що здійснюється у межах Північноатлантичного Альянсу і визначається як сукупність способів, методів, прийомів, а також відповідних організаційних структур та засобів, які застосовуються для здійснення процедур стандартизованого процесу вивчення і впровадження досвіду [3; 8-14; 19-22]. Власне дана організаційно-технічна система - це інтеграція однотипних національних систем ВВД збройних сил країн-членів Альянсу, що базуються на застосуванні загальноприйнятих понять і визначень, організаційних структур і процедур, а також на взаємному використанні Порталу ВВД НАТО (NATO Lessons Learned Portal, LLP).

В основі побудови та розвитку ОСВВД НАТО лежать головні постулати сучасної теорії управління ВВД, а також трьохетапна модель еволюції організаційного управління знаннями, що була запроваджена у збройних силах США із 1960 по 2010 рік (рис. 1) [3;11-14; 18-23]. 
$\uparrow \begin{gathered}\text { Розвиток Системи ВВД } \\ \text { у ЗС США (1960-2010) }\end{gathered}$
3. Підвищення ефективності використання колективних знань - покращення спроможностей ВВД із інтеграції зусиль для колективного вирішення проблемних питань.

2006 : призначення у військові частини аналітиків ВВД (Lessons Learned Integrators, L2I)

2007 : стандартизація електронного формату АПД ( $A A R)$

2008 : створення Об'єднаної інформаційної системи ВВД (Joint

Lessons Learned Information System, JLLIS)

2009 : запуск онлайн-додатків (MilSuite), орієнтованих на підвищення ефективності ВВД; створення у військових формуваннях

експертних рад ВВД із вирішення проблемних питань; запровадження тижнів обміну досвідом (Umbrella weeks) у формуваннях рівня бригади та вище по завершенню розгортання військ

2. Підвищення ефективності використання емпіричних (експертних) знань - забезпечення оперативного обміну бойовим досвідом, знаннями і досвідом експертів та фахівців.

2000 : розгортання груп ВВД у районах операцій

2004 : професійні форуми ЗС США (60 форумів, більше 20000 осіб)

2004 : створення Підсистеми вивчення бойового досвіду (Battle

Command Knowledge System, BCKS)

1. Підвищення ефективності використання явних знань - покращення якості збору інформації про досвід, підвищення оперативності поширення керівних документів, аналітичних матеріалів ВВД.

1960-1970 : успішна апробація АПД (AAR).

01.08 .1985 : створення центру $C A L L$

1986 : затвердження та початок фнкціонування Програми ВВД (Joint Lessons Learned Program)

1994 : створення бази даних ВВД центру $C A L L$ - інформаційної системи ВВД сухопутних військ

1997 : створення он-лайн репозиторія керівних документів, аналітичних матеріалів ВВД

$1960 \quad 1970 \quad 1980 \quad 1990 \quad 2000 \quad 2010$

Рис. 1. Трьохетапна модель еволюції організаційного управління знаннями у збройних силах США (1960-2010) Джерело: розроблено автором за даними [18-22].

По завершенню “Холодної війни” у багатьох провідних державах, насамперед у країнах-членах НАТО, одночасно $з$ широким упровадженням новітніх ІКТ спостерігався стрімкий розвиток перманентного формального підходу до ВВД [11-14]. Окрім вищезазначених засад, моделі та чинників, підгрунтям для створення ОСВВД НАТО стало функціонування Постійно діючої групи аналізу досвіду НАТО (Permanent Analysis Team), що знаходилася у Великобританії і здійснювала свою діяльність із 1978 по 1999 рік. На базі даної групи у 2000 році почалося i офіційно завершилося 2 вересня 2002 року формування Об'єднаного центру аналізу й впровадження досвіду НАТО (ОЦАВД, Joint Analysis and Lessons Learned Centre - JALLC). Прийнято вважати, що даний центр є ядром ОСВВД НАТО і дата його створення $\epsilon$ формальною датою заснування вказаної системи $[11 ; 23]$.

У країнах-членах НАТО визначено [6-8; 24], що основною метою вивчення і впровадження досвіду, насамперед бойового, є ефективне здобування та трансформування знань і досвіду. Для досягнення вищенаведеної мети застосовують формальний підхід організаційного ВВД [11-14], що передбачає ідентифікацію вивчених уроків і потенційного передового досвіду, їх поширення, розроблення обгрунтованих рекомендацій для внесення змін у діяльність, прийняття рішень, виконання належних кори- гувальних заходів і оцінювання їх ефективності, затвердження впроваджених уроків [8-11; 24].

Умовно ОСВВД НАТО зображують як “храм знань" (рис. 2) [8-9; 11], що є джерелом вивченого й упровадженого досвіду і “фундаментом” якого слугують: активна керівна діяльність командирів і начальників в організації ВВД; комфортний соціальний мікроклімат у військових колективах, відповідний менталітет, тип мислення, культура поведінки та спілкування особового складу.

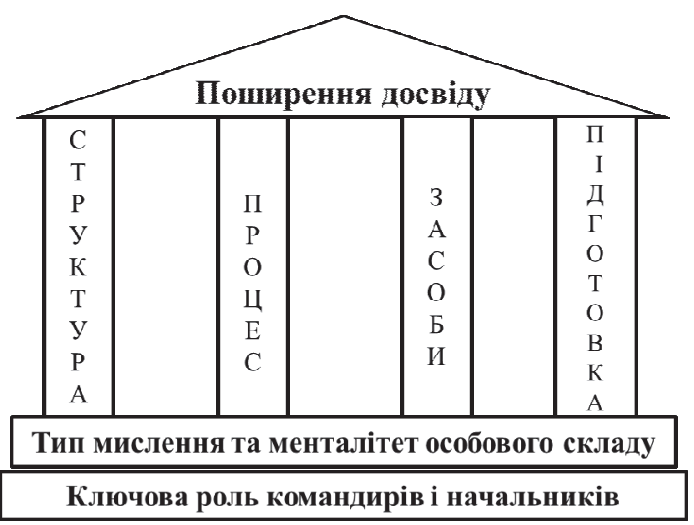

Рис. 2. Основні спроможності Об’єднаної системи вивчення і впровадження досвіду НАТО

Джерело: розроблено автором за даними [8-11].

Згідно 3 [8; 11] “колонами (опорами)” ОСВВД НАТО є наступні їі головні спроможності (рис. 2): 
1) організаційна структура ВВД, укомплектована висококваліфікованим персоналом;

2) ефективне застосування процедур стандартизованого процесу ВВД;

3) дієва підготовка особового складу із питань ВВД;

4) наявність засобів ВВД, насамперед сучасних IKT, та їх ефективне використання.

I хоча організаційне ВВД - це відповідальність кожного члена організації, для його налагодження та координації потрібна відповідна організаційна структура. ОСВВД НАТО містить органи ВВД, що входять до складу об'єднаних збройних сил (ОЗС) Альянсу і які включають дві основні категорії персоналу [3; 8-11]:

1) штатний персонал ВВД (Lessons Learned Staff Officers - LLSOs) - офіцери відділів, відділень, груп ВВД;

2) офіцери військових частин (підрозділів), установ, закладів, органів військового управління (Lessons Learned Points of Contact - LLPOCs), що призначаються відповідальними за ВВД у своїх організаціях.

У межах організаційної структури ОСВВД НАТО функціонує інтегрована мережа з 27 Спеціалізованих центрів вивчення та впровадження досвіду (СЦВВД) НАТО (Centre of Excellence - COE) [25]. Зазначені центри розташовані у різних країнахчленах Альянсу і основним призначенням відповідно до їх спеціалізації є збір спостережень, грунтовний аналіз досвіду, визначення основних причин проблем, розроблення рекомендацій і поширення уроків. Концепція створення та функціонування таких центрів була представлена у 2003 та 2004 роках у керівних документах НАТО [26-28] і перший СЦВВД був офіційно акредитований 1 червня 2005 року [25].

Сполучною та координуючою ланкою для вищезазначених органів ВВД є ОЦАВД (м. Монсанто,
Португалія), що входить до складу Стратегічного командування НАТО 3 трансформації (Allied Command Transformation) і безпосередньо підпорядковується Управлінню розвитку ОЗС НАТО (Joint Forces Development Department) [11]. Головне призначення цього центру - координація діяльності всіх органів ВВД Альянсу i, насамперед, тих органів, що здійснюють аналіз бойового застосування, підготовки, навчань і тренувань ОЗС НАТО [6-11; 23]. У межах спільної діяльності керівного складу військової структури НАТО ОЦАВД виконує наступні функції [6-10; 22]:

моніторинг імплементації політики Альянсу із ВВД на всіх рівнях військової структури та оцінювання діяльності відповідних органів ВВД НАТО;

надання консультацій і безпосередньої допомоги країнам-членам і партнерам НАТО щодо покращення їх спроможностей із ВВД;

аналіз повсякденної діяльності, воєнних та інших операцій (дій) ОЗС НАТО, організація збору та аналізу спостережень, розроблення рекомендацій, поширення вивченого і впровадженого досвіду;

участь в удосконаленні й розробленні концепцій, доктрин та інших керівних документів НАТО;

розроблення методичних матеріалів із ВВД, зокрема "Посібника $з$ вивчення та впровадження досвіду” [9] і “Посібника з аналізу досвіду” [10];

організація проведення щорічної Конференції $з$ вивчення та впровадження досвіду НАТО (NATO Lessons Learned Conference);

організація діяльності курсів підготовки офіцерів НАТО з ВВД та мобільних тренувальних груп ВВД;

наповнення баз даних Порталу ВВД НАТО та керування їх контентом, а також технічне забезпечення даного Порталу тощо.

Функціонування ОСВВД НАТО здійснюється у рамках стандартизованого процесу ВВД (рис. 3), що передбачає виконання трьох основних етапів [8-11]:

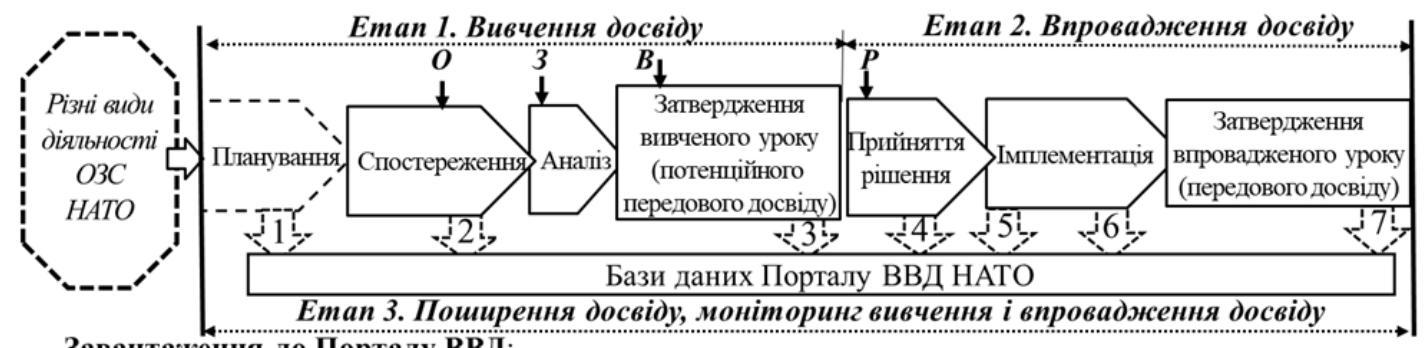

Завантаження до Порталу ВВД:

1 - план спостереження

2 - звіт про спостереження ОЗВР (О-опис проблеми 3-зміст спостереження В-висновки Р-рекомендаціi)

3 - вивчений урок (потенційний передовий досвід)

4 - рішення з впровадження досвіду із призначенням відповідального органу

5 - план заходів із впровадження досвіду

6 - результати оцінювання ефективності заходів із впровадження досвіду

7- впроваджений урок (передовий досвід)

Рис. 3. Стандартизований процес вивчення і впровадження досвіду НАТО Джерело: розроблено автором за даними [8-11]. 
1) Етап 1 “Вивчення досвіду" (Analysis), що розпочинається з моменту розроблення плану збору інформації про проблемні питання або ж із початку ведення спостережень. Протягом цього етапу: виявляють проблеми; планують і ведуть спостереження; здійснюють аналіз та узагальнення результатів спостережень і на підставі чого роблять висновки з визначенням головних причин проблем і шляхів їх вирішення. Для звітів про досвід використовують формат O3ВР (ODCR): О - опис проблемного питання (Observation); 3 - зміст спостереження (Discussion); В - висновки (Conclusion); Р - рекомендації (Recommendation) [3; 8-11]. Кінцевим і головним результатом першого етапу $\epsilon$ затвердження вивченого уроку (потенційного передового досвіду) відповідним командувачем (начальником) і завантаження уроку у Портал ВВД НАТО.

2) Етап 2 "Впровадження досвіду" (Implementation), що починається після завершення першого етапу. У ході даного етапу за результатами ретельного вивчення певних проблемних питань приймають рішення, планують і виконують необхідні коригувальні дії та оцінюють їх ефективність із метою усунення, або неповторення проблем у майбутньому, або ж зменшення їх негативних наслідків, а також для впровадження передового досвіду.

3) Етап 3 "Поширення досвіду, моніторинг вивчення і впровадження досвіду” (Institutionalization), що здійснюється упродовж всього процесу ВВД і включає (рис. 3):

розповсюдження досвіду, і насамперед, завантаження у Портал ВВД НАТО та поширення: планів і звітів про спостереження; вивчених уроків, зокрема потенційного передового досвіду; прийнятих рішень командувачів (начальників) та планів заходів iз впровадження досвіду; результатів оцінювання ефективності коригувальних дій; впроваджених уроків, у тому числі й передовий досвід;

моніторинг виконання всіх процедур процесу ВВД, насамперед, контроль визначених заходів із впровадження досвіду.

Одна з головних функцій ОСВВД НАТО - поширення знань і досвіду шляхом проведення нарад, брифінгів, інструктажів, навчальних занять; розроблення і розповсюдження друкованих і електронних видань; опрацювання та подання звітних документів із питань ВВД згідно з табелем донесень; використання Порталу ВВД НАТО, електронної пошти, вебсайтів тощо [3; 8-11;23].

Портал ВВД НАТО був створений у 2010 році на основі Інтерактивної бази даних ВВД НАТО, що містила інформацію про ідентифіковані й отримані уроки і була сформована спеціалістами ОЦАВД у 2005 році [23, С. 33]. На сьогодні Портал - це центральний вузол і ключовий засіб ВВД НАТО, що надає розширені можливості для збору інформації про спостереження й їх аналіз; підвищує оперативність поширення ідентифікованих та отриманих уроків. Також Портал забезпечує якісний моніторинг виконання процедур процесу ВВД; доступ визначеним авторизованим користувачам як до відкритої інформації, так і до даних 3 грифом ДСК і таємно; функціонування більше ніж двадцяти форумів із питань ВВД за різними напрямами діяльності $[11 ; 23]$.

Підготовка особового складу з питань ВВД займає чільне місце у системі індивідуальної і колективної підготовки ОЗС НАТО [11]. Головним чином така підготовка організована у межах мережі шести навчально-методичних курсів $[11 ; 31]$ :

дистанційний курс ВВД на платформі $A D L 138$ ( $L L P O C C)$, обов'язковий для штатного персоналу ВВД і офіцерів, відповідальних за ВВД;

виїзні курси ВВД із залученням мобільних тренувальних груп ОЦАВД (LL MTT “JATT”);

5-ти денні курси підготовки штатного персоналу ВВД у м. Кунгсанген, Швеція (LL SOC);

5-ти денні курси підготовки менеджерів з ВВД у м. Обераммергау, Німеччина ( $L L M C)$;

5-ти денні курси підготовки локальних менеджерів Порталу ВВД НАТО у м. Оейраш, Португалія (LNM - NLLP Training);

дистанційний курс ВВД (LL Training online), започаткований у зв’язку з пандемією Covid-19.

Також для підготовки командирів (начальників) усіх рівнів із питань ВВД, підвищення кваліфікації персоналу ВВД проводяться регулярні навчальні семінари, науково-практичні конференції, збори, що стосуються стану справ і розвитку ОСВВД НАТО тощо.

За результатами досліджень [11-14; 29-30] ефективність процесу ВВД і у цілому функціонування ОСВВД НАТО визначається, перш за все, якістю, актуальністю, повнотою та достовірністю інформації, що циркулює в даній системі, зокрема у Порталі ВВД НАТО. Також критичним чинником дієвості ОСВВД НАТО є ініціативність особового складу, його зацікавленість у внесенні посильного вкладу для досягнення головної мети процесу ВВД (рис. 4) - трансформація і модернізація ОЗС НАТО, підвищення ефективності їх підготовки і застосування [6-8; 11;24]. Саме тому одна 3 основних умов покращення діяльності ОЗС НАТО - це дієва реалізація процесу ВВД, кінцевим і головним продуктом якого є вивчені й упроваджені уроки, здобуті знання і досвід [6-8]. У результаті застосування організаційного ВВД [8-11; 24] (рис. 4) визначені коригувальні дії спрямовуються на підвищення комплексу спроможностей і оборонних потенціалів Альянсу DOTMLFP-I (Doctrine, Organisation, Training, Material, Leadership, Personnel, Facilities Interoperability), і насамперед, на удосконалення: 
керівних (доктринальних) документів; підготовки та взаємосумісності військ; військової освіти; організаційно-штатної структури; озброєння та військової техніки; всебічного забезпечення тощо.

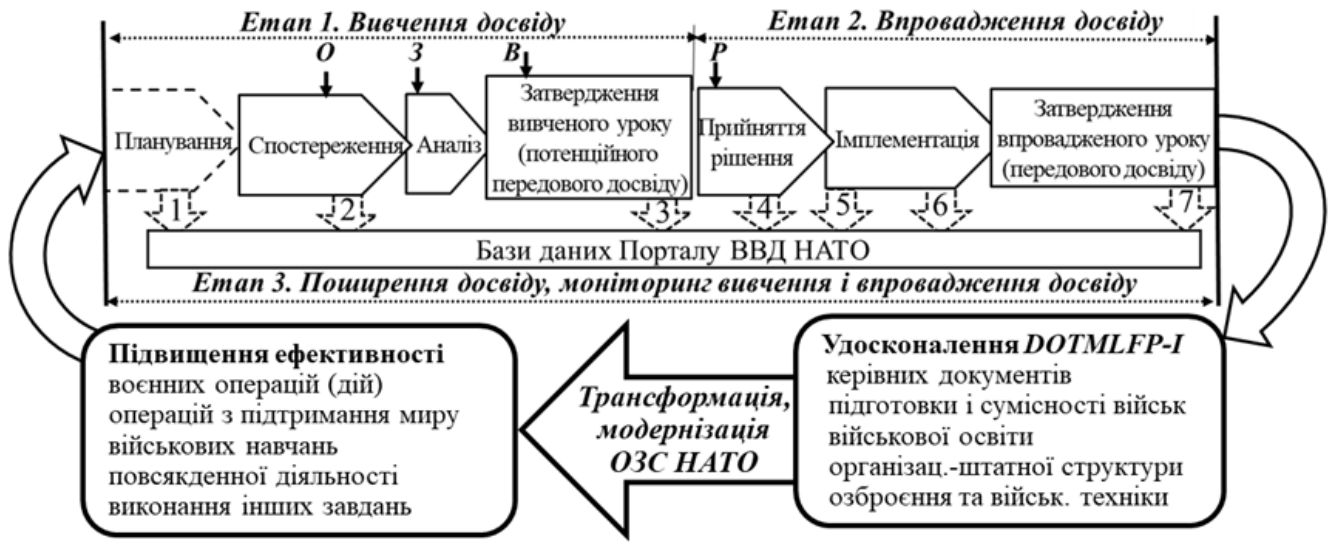

Рис. 4. Головна мета процесу вивчення і впровадження досвіду Джерело: розроблено автором за даними [8-9; $11 ; 24]$.

Як і будь-яка складна соціальна й організаційно-технічна система, ОСВВД НАТО має низку проблем у своєму функціонуванні, серед яких варто виокремити наступні [8-9; 11; 29-31]:

1) Не у всіх організаціях НАТО забезпечується належний підхід до вивчення і впровадження досвіду 3 формуванням відповідного типу мислення i культури поведінки. Особовий склад не завжди шукає інформацію про досвід (уроки) перед виконанням нових завдань, а також не застосовує всі наявні можливості та ресурси, щоб поділитися здобутим досвідом 3 іншими. Крім того, персонал окремих організацій не відчуває себе в безпеці від переслідувань командирів i начальників після надання об’єктивних звітів про спостереження, що є однією 3 причин приховування негативного досвіду.

2) Не завжди реалізовується керівна роль командирів і начальників у процесі ВВД. Не всі керівники розуміють важливість і значення організаційного ВВД і відповідно не налаштовують та навчають своїх підлеглих, а також не заохочують (винагороджують) особовий склад за оперативне поширення ідентифікованих уроків і дієве впровадження вивченого досвіду. Не завжди керівний склад організації контролює стан організаційного вивчення i впровадження досвіду, приймає своєчасні та необхідні рішення щодо імплементації й удосконалення процесу ВВД, визначає пріоритети у наданні відповідних ресурсів і надає штатному персоналу ВВД необхідну підтримку, перш за все, для моніторингу процедур поширення й упровадження ідентифікованих уроків.

3) Не у всіх штабах, частинах, установах і закладах НАТО створено дієву організаційну структуру ВВД, зокрема, не призначаються штатні офіцери ВВД, офіцери, що відповідають за ВВД, і локальні менеджери Порталу ВВД НАТО; не розробляються внутрішні інструкції ВВД із визначенням ролі, відповідальності та обов'язків посадових осіб щодо здійснення процесу ВВД, із визначенням вимог до звітності з питань вивчення і впровадження досвіду.

Не завжди штатний персонал ВВД має прямий доступ до ключових керівників, що затверджують ідентифіковані та впроваджені уроки, приймають рішення щодо коригувальних дій і призначають відповідальних за їх виконання. Частими є випадки, коли на посади штатного персоналу ВВД призначаються офіцери, що не мають належної підготовки у застосуванні методів і методик аналізу спостережень, засобів поширення інформації про досвід; у керуванні процесом ВВД і використанні процедур інформаційної безпеки. Іноді штатний персонал ВВД навіть не знає своїх обов'язків і виконує невластиві йому завдання.

4) Не у всіх організаціях НАТО у ході виконання процедур процесу ВВД заохочується самооцінка та відвертий обмін думками; здійснюється пошук, аналіз і впровадження уроків, отриманих із зовнішнього середовища, передусім уроків, завантажених до Порталу ВВД НАТО від інших організацій НАТО. Не завжди процедури процесу ВВД, і насамперед ідентифікація та впровадження досвіду, виконуються та контролюються підготовленим персоналом із питань ВВД. Ті, хто бере безпосередню участь у наданні спостережень та їх аналізі, не завжди отримують зворотний зв'язок, а також доступ до результатів подальших дій із вивчення і впровадження досвіду. У деяких штабах, частинах, установах і закладах НАТО не налагоджена ефективна реалізація стандартизованого процесу ВВД:

відсутні або неякісно розроблені, або ж не виконуються плани збору спостережень та інші планувальні документи з питань ВВД; 
не здійснюється самооцінювання та вимірювання якості виконання процесу ВВД;

отриманий раніше досвід не завжди враховується та використовується під час планування операцій (дій), військових навчань;

несвоєчасно або взагалі не завантажуються до Порталу ВВД НАТО основні результати процесу ВВД, зокрема, вивчені та впроваджені уроки, передовий досвід;

відсутня практика систематичного контролю й оцінювання дієвості впровадження досвіду, що перш за все, передбачає валідацію коригувальних дій, наприклад, грунтовне тестування нових концепцій (методик) підготовки військ, удосконалених (нових) інструкцій, настанов і методик, перевірку успішного вирішення проблемних питань під час виконання подібних завдань тощо.

5) Низький рівень підготовки 3 питань ВВД особового складу окремих штабів, частин, установ $\mathrm{i}$ закладів НАТО, де не здійснюється на належному рівні вивчення спроможностей ОСВВД НАТО згідно $з$ вимогами директиви [8], перш за все, під час підготовки до проведення операцій (дій) і військових навчань.

6) Відсутні або не застосовуються сучасні IКТ у ході виконання процедур процесу ВВД для обробки даних із забезпеченням функцій їх архівування та їх дієвим пошуком. Не дотримуються заходи з розподіленого та захищеного доступу до інформації. Не використовується шаблон ОЗВР $(O D C R)$, прийнятий у рамках НАТО для надання звітів про спостереження. Бази даних Порталу ВВД розглядаються тільки як архів інформації та не використовуються для моніторингу і менеджменту процесом ВВД.

Персонал окремих штабів, частин, установ і закладів НАТО не знає основні функції та спроможності Порталу ВВД НАТО, зокрема процедури подання запитів і звітування про результати аналізу інформації про досвід згідно з вимогами директиви [8], і відповідно не застосовує їх у своїй діяльності. Крім того, на сьогодні досі не досягнуто належного рівня технічної сумісності баз даних Порталу ВВД НАТО та національних інформаційних систем ВВД країн-членів НАТО через концептуальні розбіжності в організації процесу ВВД, різне трактування термінів і процедур ВВД і застосування відмінних форм звітів про спостереження [30, С. 3-4].

Для вирішення вищезазначених та інших проблемних питань діяльності ОСВВД НАТО застосовується системний підхід $[8 ; 11 ; 31]$. При цьому головними пріоритетами визначено створення у кожній організації НАТО комфортного соціального мікроклімату з формуванням відповідного менталітету та типу мислення, культури поведінки із питань ВВД, а також підвищення керівної ролі командирів і начальників всіх рівнів в організації та контролі процесу ВВД [6-9; 11]. Для цього, зокрема, передбачається забезпечення належної мотивації військовослужбовців щодо виявлення, аналізу та вирішення проблем; заохочування особового складу до дискусій, розвитку умінь спільними зусиллями знаходити оптимальні рішення та втілювати їх у життя. Поза тим, велика увага приділяється подальшому удосконаленню нормативної бази збройних сил країнчленів НАТО і їх партнерів. Передусім, це стосується приведення у відповідність до стандартів НАТО термінології, процедур та інформаційно-звітних документів, що стосуються вивчення і впровадження досвіду.

Ключовим напрямом розвитку організаційного ВВД у країнах Альянсу розглядається широке впровадження новітніх ІКТ у рамках процесу ВВД. Так, наприклад, у 2017 та 2021 роках було оновлено програмне забезпечення Порталу НАТО ВВД. Незважаючи на це, з метою чергового покращення спроможностей ОСВВД НАТО у 2018 році було розпочато реалізацію "Плану заміни Порталу ВВД Комплектом інструментальних засобів ВВД із застосуванням штучного інтелекту до 2025 року" [11; 31]. Головне призначення такого Комплекту - підвищити швидкість оброблення постійно зростаючих обсягів даних про досвід, надавати оперативну і грунтовну допомогу аналітикам для покращення якості аналізу інформації з питань ВВД. До складу зазначеного Комплекту планується включити потужні бази даних, сучасні системи керування цими базами, а також технології штучного інтелекту для забезпечення швидкого, інтерактивного, розподіленого та захищеного доступу користувачів до необхідної інформації. Основою для створення вказаного Комплекту стали результати роботи спеціально створеної групи фахівців із питань ВВД, до складу якої ввійшли 23 експерти з ОЦАВД та інших структурних підрозділів НАТО. Зазначені спеціалісти впродовж 9 місяців, зокрема, проаналізували зміст і структуру всіх звітно-інформаційних документів із питань ВВД (більше 450) для визначення доцільності їх подальшого використання, а також дослідили можливості застосування систем штучного інтелекту для попередньої валідації звітів про спостереження, категоризації й архівації отриманої інформації тощо $[11 ; 31]$.

\section{Висновки}

3 моменту створення інтегрованої військовополітичної структури Північноатлантичного Альянсу і до сьогодні його об'єднані збройні сили забезпечують необхідну військову потужність НАТО і 3 високою ефективністю виконують повний спектр визначених завдань [6-7; 24]. Одним із головних чинників якісної і своєчасної трансформації та модернізації ОЗС НАТО є висока дієвість Об'єднаної 
системи вивчення і впровадження досвіду Альянсу, в основі якої перманентний розвиток іiї динамічних спроможностей [8]

Поставлене у статті науково-практичне завдання $з$ дослідження спроможностей ОСВВД НАТО та тенденцій розвитку зазначеної системи має велике прикладне значення для ЗС України і є недостатньо вивченим у нашій державі. У цьому контексті слід, насамперед, ураховувати пріоритетність курсу України щодо членства в НАТО і те, що у Збройних Силах здійснюється формування перспективної Системи ВВД, яка базується головним чином на теоретико-методологічних засадах і основних принципах функціонування Об'єднаної системи вивчення та впровадження досвіду Північноатлантичного Альянсу [2-4].

\section{Список літератури}

1. Про Заяву Верховної Ради України щодо ескалації російсько-українського збройного конфлікту : Постанова Верховної Ради України від 30 квітня 2021 р. № 5312. URL: https://iportal.rada.gov.ua/news/Povidomlennya/205803.html.

2. План створення у Збройних Силах України перспективної системи узагальнення та впровадження досвіду : Міністерство оборони України № 20803 від 28.11.2018 р. 5 с.

3. Пащук Ю., Пашковський В. Методологічні підходи до формування у Збройних Силах України перспективної системи вивчення і впровадження досвіду. Наука і техніка Повітряних Сил Збройних Сил Украӥни. 2019. № 4(37). С. 36-43. https://doi.org/10.30748/nitps.2019.37.05.

4. Доктрина з вивчення та впровадження досвіду у Збройних Силах України. ВКП 7-00(01).01. 3.07.2020 p. 30 с.

5. Тимчасова інструкція вивчення та впровадження досвіду у Збройних Силах України. ВКДП 7-00(01).01. 15.07.2020 p. $72 \mathrm{c}$.

6. NATO Lessons Learned Policy. PO(2011)0293. 1 September 2011. 15 p.

7. NATO Lessons Learned Policy for Release to Partners. PO(2012)0294. 26 June 2012. 8 p.

8. Lessons Learned. Bi-Strategic Command Directive 080-006, February 2018. 25 p.

9. The NATO Lessons Learned Handbook. Lisbon : NATO Joint Analysis and Lessons Learned Centre. Third Edition. February 2016.81 p.

10. Joint Analysis Handbook. Lisbon : NATO Joint Analysis and Lessons Learned Centre. 4th Edition. February 2016, 135 p.

11. NATO Lessons Leaned Staff Officers Course (ACT.318.33). Swedish Armed Forces International Centre (SWEDINT). 03 June - 07 June 2019

12. Dyson T. The Military as a learning organisation: establishing the fundamentals of best-practice in lessons-learned. Defence Studies. 2019. Vol. 19. Iss. 2. P. 107-129. https://doi.org/10.1080/14702436.2019.1573637.

13. Dyson T. Organisational Learning and the Modern Army. A New Model for Lessons-Learned Processes. 1st Edition. London : Routledge, 2020. 276 p.

14. Dyson Tom. A revolution in military learning? Cross-functional teams and knowledge transformation by lessonslearned processes. European Security. 2020. https://doi.org/10.1080/09662839.2020.1795835.

15. Обобщение боевого опыта и доведение его до войск Красной Армии и Сил Флота. Великая Отечественная война 1941-1945 г2. В 12 т. Том 11. Политика и стратегия Победы: стратегическое руководство страной и Вооруженными силами СССР в годы войны. Москва : Воениздат, 2015. С. 695-776.

16. Cyert R., March J. A Behavioral Theory of the Firm. Englewood Cliffs. NJ: Prentice-Hall, 1963. 332 p.

17. Baskerville R., Dulipovici A. The Theoretical Foundations of Knowledge Management. London : Palgrave Macmillan, 2015. https://doi.org/10.1057/9781137552105_3. 115 p.

18. Baird L., Henderson J.C., Watts S. Learning form Action: An Analysis of the Center of Army Lessons Learned (CALL). Human Resource Management. 1997. Vol. 36. Issue 4. P. 385-395. https://doi.org/10.1002/(SICI)1099-050X(199724).

19. Dixon N.M. A Model Lessons Learned System - The US Army. 2011 Best Practices for Government Libraries. EInitiatives and e-Efforts: Expanding our Horizons. LexisNexis. P. 227-231. URL: http://www.lexisnexis.com/ tsg/gov/best_practices_2011.pdf.

20. Landry A.D. The Joint Lessons Learned System and Interoperability. A thesis presented to the Faculty of the U.S. Army Command and General Staff College, 1974. 222 p.

21. Thomas J. T., Schultz D. L. Lessons about Lessons: Growing the Joint Lessons Learned Program. Joint Force Quarterly National Defense University Press Publications. Oct. 1, 2015. P. 113-120.

22. Waliński Z. The Role of a Commander in Military Lessons Learned Systems. Journal of Corporate Responsibility and Leadership. March 2016. Vol. 2. No. 1. P. 95-106. https://doi.org/10.12775/JCRL.2015.006.

23. 15 Years of the JALLC - NATO. Lisbon : NATO Joint Analysis and Lessons Learned Centre, 2017. 160 p.

24. Allied joint doctrine for the conduct of operations. NATO Standard AJP-3. Edition C. Version 1. 2019. $164 \mathrm{p}$.

25. NATO Centres of Excellence. NATO Allied Command Transformation. URL: https://www.act.nato.int/centres-ofexcellence.

26. The NATO Military Command Structure. MC 324/1. 16 May 2003.

27. Military Command Concept for Centres of Excellence. MCM-236-03. 04 Dec 2003.

28 NATO COE Accreditation Criteria. NATO Directive IMSM-0416-04. 2004.

29. The Lessons Learned Process and Lesson Sharing in NATO and Nations. JALCC Analysis Report. Lisbon: NATO Joint Analysis and Lessons Learned Centre, August 2010.

30. Francisco G. de Paredes. Why Are Lessons Not Learned, How Can Policy and Standards Ensure Data Exchange and Truly Enable Lessons to Be Learned. Interservice/Industry Training, Simulation, and Education Conference (I/ITSEC 2020). 2020. Paper No. 20225. 10 p.

31. NATO Lessons Learned Conference 2019 Magazine (14-16 October). Lisbon: NATO Joint Analysis and Lessons Learned Centre, 2019. URL: http://www.jallc.nato.int/activities/docs/20191220_NLLC19_Magazine.pdf. 


\section{Відомості про автора:}

Пащук Юрій Михайлович кандидат технічних наук доцент

Національної академії сухопутних військ ім. гетьмана П. Сагайдачного, Львів, Україна https://orcid.org/0000-0002-0631-6183

\section{Information about the author:}

Yuriy Pashchuk

Candidate of Technical Sciences

Senior Lecturer

of Hetman Petro Sahaidachny

National Army Academy,

Lviv, Ukraine

https://orcid.org/0000-0002-0631-6183

\title{
ВОЗМОЖНОСТИ И ТЕНДЕНЦИИ РАЗВИТИЯ ОБЪЕДИНЕННОЙ СИСТЕМЫ ИЗУЧЕНИЯ И ВНЕДРЕНИЯ ОПЫТА НАТО
}

\author{
Ю.М. Пащук
}

В статье рассмотрены теоретические основы организационного изучения и внедрения опыта в вооруженных силах стран-членов Североатлантического альянса, а также исследованы исторические аспекты создания Объединенной системы изучения и внедрения опыта НАТО. Проанализированы главные возможности данной системы по четырем направлениям: организационная структура; стандартизированный процесс изучения и внедрения опьтта; подготовка личного состава по вопросам изучения и внедрения опыта; средства, используемые для изучения и внедрения опьта.

В работе также исследованы основные проблемы функционирования Объединенной системы изучения и внедрения опыта НАТО, рассмотрены тенденции дальнейшего ее развития.

Ключевые слова: опыт, организачионное изучение и внедрение опыта, возможности системы изучения и внедрения опьта, Объединенная система изучения и внедрения опыта НАТО.

\section{CAPABILITIES AND DEVELOPMENT TRENDS OF THE NATO JOINT LESSONS LEARNED SYSTEM}

\section{Y. Pashchuk}

The purpose of this work is to explore the capabilities and development trends of the NATO Joint Lessons Learned System (JLLS) for systematic formation and effective functioning of the prospective Lessons Learned System in the Armed Forces of Ukraine.

The article examines the theoretical foundations of organizational learning in the Armed Forces of the NATO member countries. It also investigates the historical aspects in forming of the JLLS. The paper focuses on creation and development of the JLLS that was based on the main tenets of the organizational learning concept and knowledge management theory, as well as formed on the evolution model of the US Armed Forces Lessons Learned System.

The article includes a comprehensive analysis of the JLLS capabilities in four areas: organizational structure with skilled and devoted lessons learned personnel; standardized lessons learned process; lessons learned training of the NATO personnel; lessons learned tools including innovative technology to support collection, storage, staffing and sharing of lessons learned information.

The paper investigates the main problems in functioning of the JLLS and considers the trends of further development of this System. A key area for the progress of organizational learning in the NATO is the widespread introduction of advanced information and communications technologies in the lessons learned process.

The work performs an important scientific and practical task in the context of the current building of the Lessons Learned System in the Ukrainian Armed Forces. The forming of the Ukrainian Lessons Learned System is carried out taking into account the experiences and best practices of the NATO member states, using the principal JLLS practical and theoretical achievements.

This approach allows exploiting the advantages of the the organizational learning in the Alliance, as well as fully embracing interoperability of the Ukrainian Army troops with NATO Joint Forces in military operations. This effort is also driven by the priorities of the Ukrainian foreign policy towards gaining NATO membership.

Keywords: experience, organizational learning, capabilities of the Lessons Learned System, NATO Joint Lessons Learned System. 